\title{
The post always rings twice? The Algerian War, poststructuralism and the postcolonial in IR theory
}

\author{
ALINA SAJED*
}

\begin{abstract}
This article makes the case for rethinking the relation between poststructuralism and postcolonialism, by building on the claims advanced by Robert Young, Azzedine Haddour and Pal Ahluwalia that the history of deconstruction coincides with the collapse of the French colonial system in Algeria, and with the violent anti-colonial struggle that ensued. I choose to examine narratives of theorists such as Derrida, Lyotard, and Cixous because not only they provide the link between colonial violence, the poststructuralist project that ensued, and postcolonialism, but also because the problems I identify with their projects are replicated by much poststructuralist work in International Relations (IR). I signal that one of the most significant consequences of conducting poststructuralist research without attention to postcolonial horizons lies in the idealisation of the marginalised, the oppressed or the native without attending to the complexity of her position, voice or agency. Bringing these theories together aims to highlight the need for a dialogue, within IR, between poststructuralism's desire to disrupt the disciplinarity of the field, and postcolonialism's potential to transcend the self-referential frame of IR by introducing perspectives, (hi)stories, and voices from elsewhere.
\end{abstract}

Alina Sajed took the position of Assistant Professor of IR with the University of Hong
Kong in September 2010. She has published an article with Citizenship Studies on the
postcolonial politics of citizenship claims by North African migrants in France. Her chapter
on biography and IR is forthcoming in Naeem Inayatullah's edited volume, Autobiographi-
cal International Relations: I, IR. She is currently working on a manuscript entitled
Transgressing International Relations. Postcolonial Encounters in the Maghreb, to be
published by Routledge for the 'Interventions' book series. Additionally, she is co-authoring
with William D. Coleman Fifty Key Globalization Thinkers, to be published by Routledge.

Postcolonial theory and research has had a fragile, often overlooked presence within the discipline of International Relations (IR). In spite of excellent studies of world politics written from postcolonial perspectives, the 'field' has been largely

\footnotetext{
* An earlier version of this article was presented at the ISA's Annual Convention in San Francisco, March 2008. General ideas drawn from this article prompted a roundtable on the postcolonial and the postmodern in IR Theory, organised for the ISA's Annual Convention in New Orleans, February 2010. I would like to thank the participants at this roundtable (Naeem Inayatullah, David Blaney, Vivienne Jabri, Himadeep Muppidi, Khadija Fritsch-El Alaoui) and the audience for engaging so passionately in debating the politics of the link between the postcolonial and the postmodern. I owe a big debt of gratitude to Will Coleman for his detailed comments and close reading of various drafts of the article. Also, I am grateful to Jenny Edkins for her engaging and thoughtful feedback to my critique. I hope our dialogue will continue. Many thanks to Marshall Beier, Eric Selbin and Robbie Shilliam for their feedback and positive reinforcement. I also want to thank the reviewers for their thorough and helpful comments and to Paola Raunio for her prompt assistance.
} 
unenthusiastic about the possibility of opening alternative spaces for thinking about 'relations international', to use Phillip Darby's expression. ${ }^{1}$ More than ever there is a need to look at the particular racial, gendered, and class inflections that help us explain and understand power in IR. In this article, I argue that postcolonial thinking has much to contribute to IR. In doing so, I suggest a rethinking of postcolonialism's relation to deconstruction and to poststructuralism, a relation that emerged from a peculiar historical context, that of the French colonial experience in Algeria. By attempting to historicise the project of poststructuralism and to retrace its colonial roots, I highlight the dangers of engaging in deconstructionist exercises without a postcolonial exposé. ${ }^{2}$

In making the case for rethinking the relation between poststructuralism and postcolonialism, I build on the claims advanced by Robert Young, Azzedine Haddour, and Pal Ahluwalia that the history of deconstruction coincides with the collapse of the French colonial system in Algeria, and with the violent anti-colonial struggle that ensued. ${ }^{3}$ I reflect on the (im)possibilities of associating postcolonialism with poststructuralism, and on the implications that such an association might pose for thinking critically about world politics. I begin by assessing Robert Young's claim that poststructuralism emerged as an anti-colonial project of resistance, born out of the experience of the Algerian War of Independence (1954-1962). ${ }^{4}$ Young's claim bears a tremendous significance for the practice of critical theory. His claim not only highlights the initial anti-colonial drive of deconstruction, but it also inevitably prompts us to ask questions about the problematic nature of current deconstructionst exercises within IR that are divorced from postcolonial perspectives.

Next, I consider three authors unmistakably associated with poststructuralism, and whose legacy has endured in critical theory: Jacques Derrida, Hélène Cixous, and Jean-François Lyotard. Their reflections on their personal experience of colonialism in Algeria are particularly relevant to a better understanding of the historical context in which the project of deconstruction became possible. I argue that between Derrida's deconstruction of logocentrism and Cixous' displacement of phallocentrism, the postcolonial subject tends to be recolonised as the wholly other whose alterity is unfathomable, and whose difference serves to refashion a knowable Western discourse. Moreover, Jean François Lyotard's experience of the Algerian War acquires the dimension of an intimate differend, which sees Lyotard becoming the same 'inventing subject', to use Cixous' term, of both the yearning desire for Algeria's liberation and emancipation, and of the condition of its impossibility. Focusing on these particular theorists illustrates the similar quandaries faced by analyses in IR that are informed by poststructuralist sensibilities.

${ }^{1}$ Phillip Darby, 'Pursuing the Political: A Postcolonial Rethinking of Relations International', Millennium: Journal of International Relations, 33:1 (2004), pp. 1-32.

${ }^{2}$ See Linda Hutcheon, 'The Post Always Rings Twice: the Postmodern and the Postcolonial', Textual Practice, 8:2 (1994), pp. 205-38.

${ }^{3}$ See Robert J. C. Young, Postcolonialism. An Historical Introduction (Oxford: Blackwell, 2001), and White Mythologies. Writing History and the West, second edition (London: Routledge, 2004); Azzedine Haddour, Colonial Myths. History and Narrative (Manchester: Manchester University Press, 2000), and 'Remembering Sartre', an introduction to Jean-Paul Sartre, Colonialism and Neocolonialism, trans. Azzedine Haddour, Steve Brewer, and Terry McWilliams (London and New York: Routledge, 2006); Pal Ahluwalia, 'Out of Africa: Poststructuralism's Colonial Roots', Postcolonial Studies, 8:2 (2005), pp. 137-54.

${ }^{4}$ Young, Postcolonialism, pp. 411-28. 
Thus, I choose to examine their narratives because they not only provide the link between colonial violence, the poststructuralist project that ensued, and postcolonialism, but also because the problems I identify with their projects are replicated by much poststructuralist work in IR.

In the last part of the article, I explore the implications of Young's claim and I discuss the impact of poststructuralism's problematic politics of difference on the practice of critical theory within IR. I retrace poststructuralism's initial drive, all the while bearing in mind the caveats posed by a reflection on origins in the context of a theory that disavows and disparages 'originary' claims. One of the major points on the poststructuralist agenda in IR has been precisely the intent to bring a sense of historicity and contingency to a field that asserted its ahistorical truths and policed them with a fierce stubbornness. ${ }^{5}$ In this respect, I attempt to historicise the project of poststructuralism, and to draw attention to the irony attending a project that is oblivious to its own historicity. I suggest that, in the context of a continued failure of IR's critical discourses to decentre the discipline, it has become more important than ever to reflect on what an honest engagement with these amnesiac practices might mean for the discipline of IR and for the practice of IR. Moreover, I signal that one of the most significant consequences of conducting poststructuralist research without attention to postcolonial horizons lies in the idealisation of the marginalised, the oppressed or the native without attending to the complexity of her position, voice or agency. ${ }^{6}$ Within critical attempts in IR at retrieving the native's voice this idealisation of the native as the other, the oppressed, and wronged/marginalised subject, speaks ironically to the notion that 'defilement and sanctification belong to the same symbolic order', which is that of colonial/imperialistic discourse. ${ }^{7}$ By exploring the poststructuralist politics of encountering otherness in Jenny Edkins' 'Exposed Singularity', I illustrate that a deconstructionist exercise, which fails to engage the contradictory and complex character of postcolonial subjects, ultimately redisciplines the 'native' as the limit of Western knowledge and sanctifies her as absolute and unfathomable difference. Also, by addressing the omission of (post)colonial contexts in Roxanne Doty's analysis of anti-immigrantism in Western societies, I highlight the consequences of engaging in a deconstructive exercise deprived of any postcolonial horizons. Leaving out the enduring effects of colonialism from a discussion on racism and anti-immigrantism in contemporary France speaks eloquently about the need to examine the unexplored assumptions of poststructuralist IR.

Poststructuralism emphasises difference both as an important focus of analysis meant to supplement IR's refusal to engage its inherent hierarchies and marginalisations, and as an analytical tool that investigates the violent dynamics of an international predicated upon exclusion and exploitation. In doing so, its contribution to the field is most valuable. However, insofar as most poststructuralist

\footnotetext{
${ }^{5}$ See, for example, the skilful analysis on historicity in IR undertaken by Richard Ashley in 'Living on Border Lines: Man, Poststructuralism, and War', in James Der Derian and Michael Shapiro (eds) International/Intertextual Relations. Postmodern Readings of World Politics (Lexington: Lexington Books, 1989), pp. 259-321.

${ }^{6}$ I thank one of the anonymous reviewers for prompting me to make this clarification.

${ }^{7}$ Rey Chow, Writing Diaspora: Tactics of Intervention in Contemporary Cultural Studies (Bloomington and Indianapolis: Indiana University Press, 1993), p. 54.
} 
analyses in IR assume that the critique of the field's Eurocentrism is a sufficient gesture for decolonising IR without meaningfully engaging otherness and difference, they fail to transcend the West as a system of reference. I thus explore the linkage between the colonial violence out of which the project of deconstruction emerged, the problematic engagement with otherness in the writings of Derrida, Cixous, and Lyotard, and the tendency of poststructuralist IR to replicate the failures signalled in my analysis of these three theorists.

I stress, however, that it is appropriate to examine not only the prospects of rethinking the colonial roots of deconstruction, but also the dangers present in associating it with postcolonialism. Accordingly, the last part of the article investigates the tensions, contradictions, but also the possibilities that arise from the association of these two theories. Bringing these theories together will contribute to the ongoing debate in IR about the need for a dialogue between poststructuralism's desire to disrupt the disciplinarity of the field, and postcolonialism's potential to transcend the self-referential frame of IR by introducing perspectives, (hi)stories, and voices from elsewhere. Maintaining a tension between these two visions of the international and of otherness without attempting to reduce one to the other can be a productive exercise. This tension might allow difference to emerge not simply as the result of deconstructing the West's knowledge of the other, but to have political and social texture outside of the deconstructionist endeavour.

\section{Rethinking theory, nativising discipline(s): disturbing the margins in Robert Young's White Mythologies and Postcolonialism - An Historical Introduction}

IR's disciplinary margins - which I identify with poststructuralist, feminist, and postcolonial views - constitute the target-spaces with which I engage. I explore these margins by reflecting upon the writings of several theorists who have greatly influenced poststructuralist practices in IR. And insofar as most critical IR views gesture towards a subalternity whose voice and dignity they intend to retrieve, I examine an unusual location for the status of native, namely in the inceptions of poststructuralism as an anti-colonial theory. This location is a borderland that has the potential to unsettle easily assumed binaries, such as East/West, inside/outside (and insider/outsider), coloniser/colonised, familiar/strange or foreign, and native/ non-native.

Robert Young treads into this borderland when he claims that poststructuralism would be better understood as an anti-colonial theory born out of the violence of the Algerian War of Independence. ${ }^{8}$ When discussing the origins of poststructuralism, Young makes the following claim:

If so-called 'so-called poststructuralism' is the product of a single historical moment, then that moment is probably not May 1968 but rather the Algerian War of Independence - no doubt itself both a symptom and a product. In this respect, it is significant that Sartre, Althusser, Derrida and Lyotard, among others, were all either born in Algeria or personally involved with the events of the war. ${ }^{9}$

${ }^{8}$ Young, Postcolonialism, p. 413.

${ }^{9}$ Young, White Mythologies, p. 32. 
As he points out, the experience of colonialism, of the Algerian War, and of the 'extreme rationalization and centralization of the French administrative system' make deconstruction become possible and give it its full meaning. ${ }^{10}$ More importantly, Young perceives deconstruction as a 'form of cultural and intellectual decolonization', which 'expos[es] the double intention separating rational method from its truth', namely the conflation of a myth with a universal truth. ${ }^{11}$ From his perspective, deconstruction, as a decolonising gesture, attempts to decentre and to expose various forms of centrisms, such as logocentrism, phallocentrism, and structural centrism. ${ }^{12}$ Insufficient attention is paid to the link between deconstruction and postcolonial project(s) by intellectuals coming from different areas of inquiry. Indeed, the relation between deconstruction and postcolonialism has been regarded with scepticism, in spite of the work of postcolonial critics such as Homi Bhabha, Gayatri Chakravorty Spivak, Robert Young, Rey Chow, Linda Hutcheon, and others, who have (some of them enthusiastically) blended the two. Deconstruction is seen to be overly preoccupied with textuality and language to tell us anything significant about the concrete mechanisms of colonial oppression, and about the contradictions of decolonisation. ${ }^{13}$

However, it is not this critique, insightful and accurate though it may be, that strikes at the heart of matter, so to speak. The tacit assumption has always been that deconstruction and postcolonialism are two distinct theories, which at times may seem complementary to each other, but which nonetheless operate with distinct premises. The project of deconstruction aims, among other things, at decentring the Cartesian subject, and at destabilising the naturalness of postEnlightenment categories such as reason, progress, and man, by exposing their contingent and historical lineage. ${ }^{14}$ In contrast, the postcolonial deals with the consequences, in their material and ideational form (whether cultural, political, economic, or social), of processes of colonisation and decolonisation. If history, understood as History, is nothing but the master-narrative of Western consciousness, then the postcolonial project aims not only at rewriting history from the vantage point of the West's 'others', but also to retrieve the absent voices, gazes and subjectivities of these 'others'. Young asserts that the task of poststructuralism/ deconstruction is best grasped as the intent to '[undo] the ideological heritage of French colonialism and [to rethink] the premises, the assumptions and protocols of its centrist, imperial culture'. ${ }^{15}$

As such, Young's claim makes a significant contribution to understanding deconstruction and postcolonialism in two ways. Not only does he trace the

${ }^{10}$ Young, Postcolonialism, p. 417.

${ }^{11}$ Ibid., p. 421.

12 Ibid., p. 417.

${ }^{13}$ In this sense, see the criticisms formulated by Arif Dirlik, 'The Postcolonial Aura: Third World Criticism in the Age of Global Capitalism', Critical Inquiry, 20 (1994), pp. 328-35; Ella Shohat, 'Notes on the Postcolonial', Social Text, 31/32 (1992), pp. 99-113; Anne McClintock, 'Postcolonialism: the Angel of History', in Imperial Leather. Race, Gender, and Sexuality in the Colonial Contest (London and New York: Routledge, 1995); and Asha Varadharajan, Exotic Parodies. Subjectivity in Adorno, Said, and Spivak (Minneapolis and London: University of Minnesota Press, 1995).

${ }^{14}$ For an extended analysis of the poststructuralist/postmodern project in IR, see Alina Sajed, 'Late Modernity/Postmodernity', in Robert Denemark et al. (eds), The International Studies Encyclopedia, Vol. VIII (Oxford: Wiley-Blackwell, 2010), pp. 4787-805.

15 Young, Postcolonialism, p. 414. 
anti-colonial impulse as the driving force of deconstruction, but also, more importantly, he implicitly makes the case that deconstruction does not make sense outside of the critique of Western Reason and History, and of the devastating impact of Western colonialism. In fact, Young is keen to stress that deconstruction, as a method of poststructuralism, has arisen as a form of 'insurrection against the calm philosophical and political certainties of the metropolis', ${ }^{16}$ at a moment when 'the fundamental conceptual systems of Europe are in the process of taking over all of humanity', ${ }^{17}$ which he identifies with the processes of 'western globalization'. In short, he writes '[i]f one had to answer, therefore, the general question of what is deconstruction a deconstruction of, the answer would be, of the concept, the authority, and assumed primacy of, the category of 'the West'. ${ }^{18}$

The most powerful implication of this position for the poststructuralist intellectual is that of an ethical responsibility. In discussing the Algerian connection between poststructuralism and postcolonialism, I do not intend to conflate these two theories. Rather, my goal is to highlight the historical roots of poststructuralism in the violence of the Franco-Maghrebian encounter. In doing so, I am able to explain and confront the failure of critical accounts within the discipline of IR, and of the postmodern project more generally, to meaningfully engage difference and allow for the emergence of alternative conceptions of world politics that go beyond a critical re-reading of the IR's 'canon'. The dangers of engaging in deconstruction without a postcolonial exposé, as Linda Hutcheon has once put it, are not insignificant. ${ }^{19}$ If the driving force of the former is to deconstruct the category of 'the West', then must one not pay closer attention to the background of Western colonialism, and to the current hegemonic status of Western thought and culture?

\section{Colonial desire and the politics of Algerian intractability: Derrida, Cixous, and Lyotard}

Derrida claims that he is 'the most Franco-Maghrebian, and perhaps the only Franco-Maghrebian', ${ }^{20}$ and Hélène Cixous refers to her 'Algeriance"21 and to herself as being 'inseparab'. ${ }^{22}$ These self-characterisations intimate a sense of difference from both the French coloniser and from the colonised 'natives', and gesture towards a colonial identity experienced as agony, filled with various potentialities and transgressions. Inhabiting neither the space of colonial privilege, nor the abjection of the colonised, Derrida and Cixous claim a peculiar native and postcolonial subject status for themselves, as members of the Jewish community in the Maghreb, whose transgression speaks about the richness and complexity of

16 Young, Postcolonialism, p. 412.

${ }^{17}$ Young, White Mythologies, p. 50.

${ }_{18}$ Ibid., p. 51, emphasis added.

19 'The Post Always Rings Twice'.

20 Jacques Derrida, Monolingualism of the Other. Or the Prosthesis of Origin, trans. Patrick Mensah (Stanford: Stanford University Press, 1998), p. 12.

${ }^{21}$ Hélène Cixous, 'My Algeriance, in other words: to depart not to arrive from Algeria', trans. Eric Prenowitz, in Stigmata. Escaping Texts (London and New York: Routledge, 1998), p. 153.

${ }^{22}$ Hélène Cixous, Reveries of the Wild Woman. Primal Scenes, trans. Beverly Bie Brahic (Evanston: Northwestern University Press, 2006), p. 24. 
both the colonial experience and its enduring legacy in contemporary social and theoretical structures. Jean-Franç;ois Lyotard uses his experience in Algeria as a teacher both as a pretext and as an impulse for in-depth analyses of the political situation in Algeria (and in North Africa in general), both during colonialism and shortly after Algeria's independence.

Exploring the colonial links in the writings of Derrida, Cixous, and Lyotard opens space for a better understanding both of the colonial context of deconstruction, and of the recurrent tendency of poststructuralist authors in IR to sanctify their own exile and the difference of their others. The latter involves an unqualified assumption of marginality and self-estrangement, which precludes other voices from making meaningful claims to a marginal status or from being heard. ${ }^{23}$ Theirs is a colonial desire that disguises itself as intractability of the other. Such a desire emerges from their persistent preoccupation with subverting the imperial language - Derrida and Cixous' monolanguage - from within, and with the intractability and the elusive character of the (Algerian) other, who becomes the limit of Western knowledge. Thus, an analysis of the autobiographical narratives of these three poststructuralist theorists will seek to highlight those themes that mirror the failures of current poststructuralist critiques in IR to transcend the Western-centric frame of the discipline and to engage otherness and difference in a productive dialogue. Very much like the poststructuralists writing during the Algerian War, contemporary poststructuralist analyses in IR work under the assumption that subverting the imperial language from within constitutes a sufficient act of decolonisation of the discipline. They fail to see that this step might be only the beginning to a more open-ended process of initiating a dialogue with difference and subverting their self-imposed marginality. Inadvertently following in the footsteps of Derrida, Cixous, and Lyotard, poststructuralist critiques of the discipline offer an image of the other reduced to its utter intractability and inscrutability as a resistant image against the West.

\section{Subverting the imperial language from within}

In Monolingualism of the Other, Derrida uses his own monolingualism as a pretext for an incursion into the aporias of his own identity or better said, his identification. ${ }^{24} \mathrm{He}$ writes of the (im)possibilities that underlie the construction of a hyphen (the Franco-Maghrebian hyphen): he is an Algerian Jew who speaks only French, a language that is not his 'own'. ${ }^{25}$ A hyphen does not represent an amalgamation or a unity, but the violent imposition (or better said juxtaposition)

${ }^{23}$ See, for example, Richard Ashley's thought-provoking critique of poststructuralist IR's propensity towards self-estrangement in his 'The Achievements of Poststructuralism', in Steve Smith, Ken Booth, and Marysia Zalewski (eds), International Theory: Positivism and Beyond (Cambridge: Cambridge University Press, 2002), pp. 240-53.

${ }^{24}$ For interesting evidence to support the links between Derrida's deconstruction, autobiography and postcoloniality, see Lee Morrissey, 'Derrida, Algeria, and "Structure, Sign and Play", Postmodern Culture, 9:2 (1999) [electronic source], and Jane Hiddleston, 'Derrida, Autobiography and Postcoloniality', French Cultural Studies, 16:3 (2005), pp. 291-304.

25 Derrida, Monolingualism, p. 25. 
of two terms, in this context, of two heterogeneous realities. ${ }^{26}$ But interestingly enough, the French term used for it is trait d'union. The French meaning of 'union' echoes Étienne Balibar's understanding of the violent union between France and Algeria, who claims that these societies cannot be regarded as separate entities, insofar as they are still very much bound together, 'for France today was made (and doubtless is still being made) in Algeria, with and against Algeria'. ${ }^{27}$ One can only infer that the treacherous hyphen (Franco-Maghrebian) is the most appropriate sign for his relation to Algeria, because it never fully incorporates one term into the other; it leaves them slightly parted and divided.

When pondering his relationship with the French language, Derrida divulges that his deep desire was to 'make something happen to this language', 'making the language to come to him, forcing then the language to speak itself by itself, in another way, in his language' ${ }^{28}$ But as Derrida remarks a bit later, this dream, this desire, constituted his 'independence from Algeria', his 'nostalgeria'. ${ }^{29}$ Is Derrida's 'nostalgeria', in his fusion of 'nostalgia' and 'Algeria', the expression of a defeat, of having been seduced by the master's language, the other's language, the one that is not his 'own'?

In contrast, Cixous' relationship with Algeria is one of desired fusion. Such a desire appears to be expressed linguistically, in the form of ' $I$ thought I am inseparab', 'my father an arabizarre', 'my Disalgeria', 'the malgerian force of imagination', 33 and 'my Algeriance'. ${ }^{34}$ These terms express not only states of mind and of the heart in regards to her peculiar Algerian identity, but also they evoke a sense of an ever elusive absence as presence, an unattainable entity named Algeria. Moreover, such terms suggest a deep desire to effect a rupture within the monolanguage, the only language that she speaks. This rupture would manifest itself through the insertion of Algeria's memory into the materiality of language, and thus disrupt the very logic of monolanguage by opening space for ambivalence and heterogeneity.

It appears that Derrida's and Cixous' agonising proximity to and their self-avowed desire for the master's language and for subverting it from within have turned out to be the master-narrative of deconstruction. The desire to deconstruct Western logocentrism seems to translate itself into an almost exclusive preoccupation with logocentrism, so that language becomes both the object and the subject of desire. Derrida's paradoxical task of translating into the monolanguage, into 'the only French culture [he has] at [his] disposal' a language and a culture to which his access was marked by an interdict, prompted him to attempt to

26 The fate of the Algerian Jewry is a peculiar one: after the French conquered Algeria in 1830, the French government granted French citizenship to the Jews in Algeria, in 1870, through the Crémieux decree. This constituted the first rift between the Algerian Jewish community and the Muslim population of Algeria. But the decree was revoked in 1943, by the Vichy government, which implied that a community who had managed to imagine itself as 'French' now no longer belonged anywhere.

27 Étienne Balibar, 'Algeria, France: One Nation or Two?', in Joan Copjec and Michael Sorkin (eds), Giving Ground: the Politics of Propinquity (London: Verso, 1999), p. 162.

${ }^{28}$ Derrida, Monolingualism, p. 51.

${ }^{29}$ Ibid., p. 52.

${ }^{30}$ Cixous, Reveries, p. 24.

${ }^{31}$ Ibid., p. 25.

${ }^{32}$ Ibid., p. 39

${ }^{33}$ Ibid., p. 64.

34 Cixous, 'My Algeriance', p. 153. 
destabilise the monolanguage from within. ${ }^{35}$ Insofar as this exercise was selfreferential par excellence (both in its intent and in its method), deconstruction often slips into reconstruction and recontainment.

There is an unmistakable desire for and move towards subversion in Derrida's and Cixous' reflections on their Algerian experience, in their denunciation of ethnocentrism, Western logocentrism, and racism. But when such a desire for subversion is linked with a self-referential enterprise that fails to step outside of the boundaries of Western discourse, and that does little to encounter otherness in a meaningful way, subversion metamorphoses into recontainment, ${ }^{36}$ as it will be examined next.

\section{Algerian intractability and colonial desire}

As Cixous confesses in the opening of 'My Algeriance', '[t]he whole time I was living in Algeria I would dream of one day arriving in Algeria, I would have done anything to get there, I had written, I never made it to Algeria [. . . '. ${ }^{37}$ Algeria can never be possessed, attained or understood. It seems that, as Lyotard himself would put it, Algeria constitutes an 'intractability', an absence as presence, which always eludes the one who desires her. Such an intractability arises not only for the one who never interacts with her, but also, and perhaps especially for the one who is born there but who does not quite belong there, as both Cixous and Derrida conclude.

Insofar as Cixous' recollection of Algeria suggests feelings of elusiveness, unattainability, of a thoroughly enigmatic absence as presence, one can sense an aura of exoticism, mystery and reification of otherness. Alterity or difference seems to become, in the being in/of Algeria, incarnate alterity, whose otherness one cannot hope to know or fathom. In Woman and Chinese Modernity, cultural critic Rey Chow remarked that critical discourses of the non-West produce an Other 'that is deprived of fantasy, desires, and contradictory emotions' ${ }^{38}$ In contrast, in her autobiographical essay, Cixous produces an Algeria who is nothing but incarnate desire, fantasy, and contradictory emotions. Cixous' Algeria acquires an almost spectral presence, a phantasmatic expression of otherness that is felt as presence only insofar as it is crystallised as the unknown and the unknowable.

In the short essay, 'The Name of Algeria', Lyotard defines the 'intractable [intraitable]' as '[t]his stake, which motivates the carrying on of resistance by other means, on other terrains, and perhaps without goals that can be clearly defined'. ${ }^{39}$ As Winifred Woodhull points out, in Transfigurations of the Maghreb, Lyotard seems to locate a moment of depoliticisation of the French society during the Algerian War (or perhaps with the Algerian War), so that the intractable/the

35 Ibid., p. 70.

36 Varadharajan, Exotic Parodies, p. 21.

37 Cixous, 'My Algeriance', p. 153.

${ }^{38}$ Rey Chow, Woman and Chinese Modernity. The Politics of Reading Between West and East (Minneapolis: University of Minnesota Press, 1991), p. xiii.

${ }^{39}$ Lyotard, 'The Name of Algeria', in Political Writings, trans. Bill Readings and Kevin Paul Geiman (Minneapolis: University of Minnesota Press, 1993), p. 166. 
differend must be located and explored elsewhere, ${ }^{40}$ 'on other terrains'. Thus the name of Algeria is one of an intractable difference, which will make itself known through other means or in other locations, identified by Lyotard in his Differend as follows: 'What is at stake in a literature, in a philosophy, in a politics perhaps, is to bear witness to differends by finding idioms for them'. ${ }^{41}$

Winifred Woodhull expresses her discontent with Lyotard's assessment of intractability. In her view, to consider the Algerian experience as intractable, glosses over the very grounded and grassroots mobilisations that have taken place in Algeria among students, intellectuals, women, and Berbers. Similar to Derrida and Cixous, Lyotard takes the West as the point of reference and the primary location of the political: he claims that 'the voice of the intractable difference no longer makes itself heard, in Western societies, in social or political channels'. ${ }^{42}$ Consequently, this intractable difference can only manifest itself in poetic/aesthetic and philosophical realms. Such a categorical statement moves Lyotard to claim that since radical Marxist politics have lost their intelligibility (in the West), other political struggles - 'those of youths, immigrants, women, homosexuals, prisoners, or peoples of the third world' - cannot effect a meaningful change. ${ }^{43}$

Edward Said remarked that ' $[\mathrm{t}]$ he ideologies of imperialism and the critiques of imperialism [...] shared the same historicist premises'. ${ }^{44}$ This critique applies to the already quoted passage by Lyotard. Insofar as 'activities of free spontaneity' do not revolve around the programme and the tenets endorsed by radical Marxism, they have very little chance of exerting a significant impact. Thus, should one assume that struggles related to issues of race, gender, and (neo-)colonialism do not have much chance of being political (and politicising), simply because Marxism has lost 'its intelligibility and substance' (in the West)? ${ }^{45}$ As for Cixous' desire 'to get out of FrenchAlgeria for lack of Algeria, ${ }^{46}$ one cannot escape the fantasy of nativism that seems to radiate from her narrative.

I make this argument having sensed a certain nativisation of Arabs and of 'Arabitude' (as Cixous calls it), which prevents her from conveying to the reader a more nuanced and contradictory picture of Algeria. She mentions 'the unshakeable certainty that "the Arabs" were the true offspring of this dusty and perfumed soil', or that 'the Arabs [were] [...] the earliest "arrivals" in this land' ${ }^{47}$ It is understandable that Cixous makes such statements to counter the French colonial claims, and in solidarity with the colonised population of Algeria. But her 'unshakeable certainty' needs to be vastly qualified in a text that talks about colonial violence. Her totalised and unnuanced victimisation of Arabs obscures the ways in which such an oppression did not prevent other groups from being oppressed by Arabs, such as the Berbers, the Touaregs, the black Africans, the

${ }^{40}$ Winnifred Woodhull, Transfigurations of the Maghreb. Feminism, Decolonization, and Literatures (Minneapolis: University of Minnesota Press, 1993), p. xvi.

${ }^{41}$ Lyotard, The Differend: Phrases in Dispute, trans. Georges Van Den Abbeele (Minneapolis: University of Minnesota Press, 1988), p. 13.

42 Lyotard quoted in Woodhull, Transfigurations, p. xvii.

${ }^{43}$ Lyotard, 'The Name of Algeria', p. 169, emphasis added.

44 Said quoted in Young, White Mythologies, p. 2.

45 Woodhull, Transfigurations, pp. xvi-xviii. For an extended critique of Lyotard's politics, see Woodhull's 'Introduction' to her Transfigurations of the Maghreb.

${ }^{46}$ Cixous, Reveries, p. 81.

${ }^{47}$ Cixous, 'My Algeriance', pp. 153, 162. 
Jews (!), and others. ${ }^{48}$ Therefore, one needs to be very careful when operating with 'unshakeable certainties' and when assigning indisputable labels of victimhood and oppression. This sort of enigmatic nativism, which precludes the 'inventing subject' from perceiving the other as ridden with tensions and ambivalence also relegates the other as the (unknowable) limit of Western discourse's knowledge.

Between Derrida's deconstruction of logocentrism and Cixous' displacement of phallocentrism, the postcolonial subject tends to be recolonised as the wholly other whose alterity is unfathomable, and whose difference serves to refashion a knowable Western discourse. Lyotard becomes the subject of an intimate differend: Lyotard, the lover of Algeria, desires his beloved's 'liberty', as he puts it, and her liberation from colonial occupation; ${ }^{49}$ but Lyotard, the radical Marxist, knows that, insofar as radical discourses and practices of emancipation 'have lost their intelligibility and substance', this lover's desire is somewhat futile. The lover's lament is thus the lover's differend, insofar as he is the same 'inventing subject', to use Cixous' term, of both the yearning desire and of the condition of its impossibility.

\section{The (im)possibilities of theoretical miscegenation: what is at stake in associating poststructuralism and postcoloniality in International Relations?}

\section{Self-referentiality and the ever elusive 'other'.}

In conceptualising the notion of 'differend', Lyotard remarks that such a notion can be perceived as 'the case where the plaintiff is divested of the means to argue and becomes for that reason a victim, ${ }^{50}$ As both Derrida and Cixous point out, they are the (postcolonial) subjects of a historical paradox: they both experienced French colonialism (with its discriminatory effects), but the only language in which they can express this experience is French, the only language they speak, but which is not their own. ${ }^{51}$ In Lyotard's terms, their narratives constitute instances of an impossibility of bearing witness to the injustice of their condition. Therefore, their projects attempt to subvert the only language they speak from within, and 'make something happen' to it, as Derrida confesses. ${ }^{52}$ The problem arises from the implications that such self-referential projects pose for imagining and understanding postcoloniality.

In short, deconstruction (at least the kind that is associated with Derrida, Cixous and Lyotard) emerged out of an anti-colonial stance, as a project of

${ }^{48}$ For in-depth investigations of the linguistic complexities of the Maghreb, and of the recolonisation projects undertaken by post-independence Maghrebian states with regards to the ethnic, linguistic, and religious diversity that constitutes the North African region, see Alek Toumi, 'Creolized North Africa: What Do They Really Speak in the Maghreb?', in Marie-Pierre Le Hir and Dana Strand (eds), French Cultural Criticism: Criticism at the Crossroads (Albany: State University of New York Press, 2000), pp. 69-80; and also his Maghreb divers (New York: Peter Lang, 2002).

49 Lyotard, 'The Name of Algeria', p. 170.

50 Lyotard, The Differend, p. 9.

${ }^{51}$ Cixous makes mention of a sort of multilingualism going on in her family, on account of her parents coming from different backgrounds ('My Algeriance', p. 168). Yet, she identifies herself as as 'a book of apocalypses written in a language I don't speak' and 'hav[ing] no author' (Reveries, p. 71, emphasis added).

52 Derrida, Monolingualism, p. 51. 
displacement and subversion of the category of 'the West', in the context of the Algerian War against French colonialism. I have thus argued that deconstruction and postcolonialism are intimately linked. These links are currently found in the works of postcolonial theorists such as Homi Bhabha, Robert Young, and Gayatri Chakravorty Spivak - who want to 'make something happen' to deconstruction by grafting it onto postcolonial analysis. Within IR, there have been a few attempts to link these two approaches and to move beyond a critique of the discipline from within. ${ }^{53}$ However, most researchers working within poststructuralist and postcolonial approaches have preferred to express suspicion towards the effectiveness of the subversion envisioned by either the poststructuralist or the postcolonial projects. In IR, deconstruction entails a set of practices, which aim to render strange the boundaries, the self-identity and the central objects of research of the discipline, and thus to 'to deconstruct or denaturalize through detailed interpretation the inherited language, concepts, and texts that have constituted privileged discourses in international relations'. ${ }^{54}$ On the other hand, postcolonial voices in IR have drawn attention to the endurance of the Western-centric frame of the discipline, and more particularly have addressed the politics of silence that have excised non-Western perspectives and (hi)stories from the study of world politics.

Therefore, the joint consideration of the colonial roots of deconstruction and of the association between poststructuralism and postcolonialism is important for ethical positioning. To practice deconstruction bearing the colonial background in mind pushes the researcher to go beyond an exercise that begins with the category of 'the West' (albeit in a subversive and critical mode) and that ends up reconstituting the image of the West without significant attention paid to other voices beyond the West. Deconstruction informed by (post)colonial perspectives opens the door to a much needed balance between too narrowly defined oppositional politics - a common criticism advanced by postmodernist approaches against postcolonial endeavours, and analyses that lack the groundedness and the deeply politicised positions (stemming from historical contexts), which deconstruction often lacks. ${ }^{55}$ By drawing attention to the colonial roots of poststructuralism and to the linkage between the project of deconstruction and the violence of Algerian decolonisation, this analysis highlights a crucial omission from current poststructuralist analyses in IR. This omission of the colonial background of deconstruction is marked by the following irony: a critical project that aims to subvert the discipline of IR by exposing the historicity of its most cherished categories and thus refuting their alleged universality, operates within a dehistoricised framework, unaware of its own colonial legacy. How shall we make sense of

${ }^{53}$ See, for example, Vivienne Jabri's 'Solidarity and Spheres of Culture: The Cosmopolitan and the Postcolonial', Review of International Studies, 33 (2007), pp. 715-28; Roland Bleiker's Aesthetics and World Politics (Basingstoke: Palgrave Macmillan, 2009), Debbie Lisle's The Global Politics of Contemporary Travel Writing (Cambridge: Cambridge University Press, 2006); Nevzat Soguk's 'Transversal Communication and the Euro-Kurds', Review of International Studies, 34 (2008), pp. 173-92, and Costas Constantinou's States of Political Discourse: Words, Regimes, Seditions (London: Routledge, 2004).

54 James Der Derian, 'The Boundaries of Knowledge and Power in International Relations', in James Der Derian and Michael Shapiro (eds) International/Intertextual Relations: Postmodern Readings of World Politics (Lexington: Lexington Books, 1989), p. 4.

${ }^{55}$ I signal here an edited volume by Pheng Cheah and Suzanne Guerlac, Derrida and the Time of the Political (Duke University Press, 2009), which aims to dispel the commonly-held assumption of a disconnect between deconstruction and politics. 
this contradiction? One possible explanation could be that contemporary analyses of poststructuralist IR, just like Derrida, imagine themselves exonerated of the task to scrutinise their own assumptions. Since they constitute themselves as the margins of the discipline, they see their endeavours cleared by default of any potential or blatant orientalism. To put it differently, it is intriguing that such critical projects have not yet seriously entertained the possibility that their own horizons and assumptions might be in need of decolonisation.

These criticisms are inspired, in part, by Rey Chow's critique of Derrida's representation of Chinese writing in Of Grammatology. In a typically absorbing analysis, Chow deconstructs Derrida's own implicit orientalism in his seminal work. Derrida's text attributes 'imagined, fantastical qualities to the East without paying attention to its reality'. ${ }^{56}$ Derrida uses the stereotype of Chinese writing as an ideographic language and crystallises its erroneously represented nature into the West's other, who escapes scrutiny and proper comprehension. ${ }^{57}$ For this reason, the East becomes nothing more than the 'name of the limits of the text's knowledge', as Spivak aptly points out in the preface to her English translation. ${ }^{58}$ The paradox is that a method that aims at subverting the category of the West ends up reifying (and impersonating!) the very 'metaphysics of presence' it denounces! ${ }^{59}$ Rey Chow assesses that 'Derrida's Chinese writing [acts] as a spectre, a kind of living dead that must, in his philosophizing, be preserved in its spectrality to remain a utopian inspiration'. ${ }^{60}$

I should clarify, at this point, my stance on the (im)possibilities of associating poststructuralism/deconstruction and postcolonial theory. Although I am compelled by Robert Young's argument that deconstruction emerged out of an anti-colonial impulse, I do not think it lived up to its initial impulse. And that is precisely why I think it is crucial that a re-association between deconstruction and postcoloniality be made. One of the frames within which this re-association needs to happen is that of an ethical responsibility. Derrida (and following in Derrida's footsteps so many other intellectuals, including myself) adopts an ethical positioning that moves from an 'intractable singularity' (his experience of (post)colonial Algeria) to a 'prudent and differentiated universalization', ${ }^{61}$ for fear that focusing on more collective approaches to colonialism might make the project of deconstruction a reductive one. ${ }^{62}$ When such a move is constantly performed, what emerges is an apologia for self-referentiality (masked as the transparency or effacing of the subject) on account of the subject being able only to speak for himself, so that the other might be allowed her own voice.

This systematic refusal to speak for others (while laudable in its intent) translates (also systematically) into a gesture of absolving oneself of the 'responsibility for the brutality of history'. ${ }^{63}$ This refusal becomes another doubly

\footnotetext{
${ }^{56}$ Chow, 'How (the) Inscrutable Chinese Led to Globalized Theory', PMLA, 116:1 (2001), p. 70.

57 Ibid.

58 Gayatri Chakravorty Spivak, 'Translator's Preface', in Of Grammatology, Jacques Derrida (Baltimore: John Hopkins University Press, 1976), p. lxxxii.

59 See Derrida's 'La structure, le signe et le jeu dans le discours des sciences humaines', in L'Écriture et la différence (Paris: Éditions du Seuil, 1967).

${ }^{60}$ Chow, 'How (the) Inscrutable Chinese', p. 72.

${ }^{61}$ Derrida, Monolingualism, p. 23.

${ }^{62}$ Cf. Hiddleston, 'Derrida, Autobiography and Postcoloniality', p. 293.

${ }^{63}$ Varadharajan, Exotic Parodies, p. xvi.
} 
recolonising gesture. Firstly, the Western critic attributes to herself/himself the 'right to grant the other "permission to narrate" her (hi)story'. ${ }^{64}$ Secondly, this much-extolled reflexivity implies that the 'other' constitutes a 'barrier' of some sort, ${ }^{65}$ an inscrutable and wholly different other that serves the same purpose and plays the same role as Derrida's exotic representation of Chinese writing. What was intended as a reflexive and critical auto-ethnography, becomes an ethnography that paralyses the other into a stereotypical frame of difference and exoticism. Moreover, moving beyond Varadharajan's insightful critique of poststructuralist reflexivity, it is not reflexivity per se that is problematic. Reflexivity is desirable and highly necessary in the work of deconstruction. It is a particular aspect of reflexivity that needs to be questioned: that of focusing so much on the autoethnographic/self-referential dimension of subjectivity that the other is usually treated in an anecdotal or mystifying way. I develop this criticism later when I engage Jenny Edkins' politics of subjectivity and otherness outlined in her article 'Exposed Singularity'.

As the refusal to speak for others (in the hope that the others will speak for themselves) unfolds in the works of deconstructive IR, the implicit assumption that emerges (between the lines) is that otherness is 'radical and irreducible'. ${ }^{66}$ Such a vision of otherness produces a sanctification of the 'native', which, in Rey Chow's understanding, stems from a 'Third Worldist fantasy' of the Western critical intellectual, whose strategy is a 'rhetorical renunciation of the material power that enables her rhetoric'. ${ }^{67}$ This strategic renunciation, Rey Chow identifies as the 'productivity of the white guilt', whose fantasy of the absolute and total difference of Eastern from Western societies translates itself (textually and materially) into a representation of otherness that rematerialises the binary structure (West/East; West/Other) deconstruction claims to have subverted. To put it differently, a project that aims at developing a practice of responsibility to the other (to use an expression frequently encountered in the analyses of poststructuralist IR scholars such as Jim George, David Campbell, Roxanne Doty and Jenny Edkins) continues to silence those on the margins, by speaking over their voices.

\section{Deconstructive and postcolonial politics in IR}

This discussion on the claims of poststructuralism to an effacement of the subject, and consequently, to a refusal to speak for others, takes me into a problématique that has been an important concern of critical approaches to IR. The question of why critical IR should be concerned with the politics of subjectivity seems to require no elaboration. One of the most prominent points on the poststructuralist agenda has been the deconstruction of IR's disciplinary practices of subjectivity.

${ }^{64}$ Ibid., p. xvii. See, for example, Jim George's Discourses of Global Politics: A Critical (Re)Introduction to International Relations (Boulder: Lynne Rienner, 1994), and 'Realist "Ethics", International Relations, and Postmodernism: Thinking beyond the Egoism-Anarchy Thematic', Millennium: Journal of International Studies, 24:2 (1995), pp. 195-223.

65 Ibid.

${ }^{66}$ Varadharajan, Exotic Parodies, p. vii.

${ }^{67}$ Chow, Writing Diaspora, pp. 10-11. 
But why critical IR should take seriously the possibility of associating postcolonialism with poststructuralism is an interrogation that requires further reflection.

The encounter between IR and deconstruction can be situated within a particular nexus, that between postmodernist/poststructuralist and postcolonial approaches. ${ }^{68}$ As mentioned earlier, the endeavours of poststructuralist intellectuals within IR spring from an ethical desire to undermine ultimate claims to truth, to allow otherness and difference to express themselves, and to demystify concepts and standpoints that make claims to neutrality and universality. ${ }^{69}$ But such tenets do not necessarily translate into genuine space-clearing gestures ${ }^{70}$ that might include various alternatives of being-in-the-world, nor into meaningful engagements with difference and otherness. Poststructuralists' current adherence to contingency and historicity seems to preclude an inquiry into the historical background of deconstruction, and into the 'imperial conceit' that emanates from the texts of many postmodern theorists whom poststructuralists in IR view as mouthpieces for emancipation. Sankaran Krishna notes, for example, how there is very little engagement with and reflection on some of the problematic statements concerning the 'Third World' coming from prominent figures such as Jean Baudrillard, Julia Kristeva, Jacques Derrida, Jean-François Lyotard and Michel Foucault, among others. He remarks that it is indeed ironic that 'a movement supposedly so sensitive to the historicization of social categories and knowledge practices as postmodernism is should also be so amnesiac regarding its own origins'. ${ }^{71}$ It is precisely out of a concern with knowledge practices or rather with a certain manner of practicing critical knowledge in IR that an incursion into the colonial roots of poststructuralism is undertaken here. I view such an incursion not only important but imperative, if the self-avowed task of decentring Western visions of world politics is to be taken seriously.

I retrace the colonial roots of deconstruction as an illustration of its ambivalence not only regarding its self-proclaimed marginality in IR, but also regarding the marginality of those (post)colonial others, whose voices are still

68 There are IR scholars who have made conscious efforts to combine both perspectives. In this regard, see, among others, Nevzat Soguk, States and Strangers. Refugees and Displacements of Statecraft (Minneapolis: University of Minnesota Press, 1999); Sankaran Krishna, Postcolonial Insecurities: India, Sri Lanka, and the Question of Nationhood (Minneapolis: University of Minnesota Press, 1999); Anna Agathangelou and L. H. M. Ling, 'The House of IR'; L. H. M. Ling, Postcolonial International Relations: Conquest and Desire Between Asia and the West (New York: Palgrave Macmillan, 2002); Michael Shapiro, Methods and Nations. Cultural Governance and the Indigenous Subject (Abingdon: Routledge, 2004); J. Marshall Beier, International Relations in Uncommon Places: Indigeneity, Cosmology, and the Limits of International Theory (New York: Palgrave Macmillan, 2005); Peter Nyers, Rethinking Refugees: Beyond States of Emergency (London and New York: Routledge, 2006); Roland Bleiker, 'Traversing Patagonia: New Writings on Postcolonial International Relations', Political Theory, 36:2 (2008), pp. 313-20.

${ }^{69}$ See, here, the by now 'classic' studies, of James Der Derian and Michael Shapiro (eds), International/Intertextual Relations. Postmodern Readings of World Politics (Lexington: Lexington Books, 1989); Jim George, Discourses of Global Politics; Richard Ashley and Rob Walker, 'Reading Dissidence/Writing the Discipline: Crisis and the Question of Sovereignty in International Studies', International Studies Quarterly, 34:3 (1990), pp. 367-416; Rob Walker, Inside/Outside: International Relations as Political Theory (Cambridge: Cambridge University Press, 1993).

${ }^{70}$ I owe this expression to Anthony Appiah, 'Is the Post in Postmodernism the Post in Postcolonial?', Critical Inquiry, 17 (1991), pp. 336-57.

${ }^{71}$ Sankaran Krishna, 'The Importance of Being Ironic: A Postcolonial View on Critical International Relations Theory', Alternatives, 18:3 (1993), p. 416, n. 40. 
sorely lacking from the conversation. ${ }^{72}$ More to the point, if poststructuralist IR does wish for a genuine practice of conversation to emerge then it needs to not only acknowledge but also perform its provisional location. This location fluctuates between the marginality of the colonial experience in Algeria that made deconstruction possible, and 'the simultaneous disavowal of that marginality which puts deconstruction at the centre of European thought'. ${ }^{73}$ Following in the footsteps of Derrida's deconstructive work, theorists like Richard Ashley, Rob Walker, Jim George, David Campbell, Cynthia Weber and others, deconstruct IR's long cherished disciplinary landmarks, such as: the state as the main actor in International Relations; ${ }^{74}$ the concept of state sovereignty; ${ }^{75}$ the 'founding' texts of IR; ${ }^{76}$ and America's foreign policy. ${ }^{77}$

These deconstructive exercises have been immensely beneficial insofar as they have demonstrated that IR's disciplinary claims to its own area of expertise stem from a hegemonic imposition of Western (really American) perspectives as regards world politics. $^{78}$ Indeed, they have exposed IR as a self-referential Western discipline, which takes the West (mainly the US) as the main point of reference for global politics. It then designates its founding texts, its relevant actors, and its main concerns within the jealously guarded boundaries of this 'centred structure' (Derrida's expression). But insofar as such critical deconstructive projects have limited themselves to the deconstruction of US foreign policy, and to that of the main elements with which mainstream IR traditionally operates, they have inadvertently reinscribed the limits of the field, and more generally, the limits of the knowable. Just as Derrida used Chinese writing to inscribe the limits of Western knowledge, so such critical deconstructive attempts in IR have used non-Western concepts and practices as the names of the limits of IR, to paraphrase Spivak's critique of Derrida. The paradox that haunts deconstruction as is currently practiced is that, even as it stems from an anti-colonial and anti-Western drive, it does not manage to transcend 'the West' as a system of reference.

Poststructuralist approaches in IR have been painfully concerned with illuminating other spaces of knowledge, with bringing to light those 'subjugated knowledges' that speak about other ways of being, about other ways of

${ }^{72}$ See Pal Ahluwalia, 'Out of Africa'.

73 Ibid., p. 145.

${ }^{74}$ Richard Ashley, 'The Poverty of Neorealism', in Robert O. Keohane (ed.) Neorealism and Its Critics (New York: Columbia University Press, 1986); Roxanne Doty, Anti-Immigrantism in Western Democracies. Statecraft, Desire, and the Politics of Exclusion (London and New York: Routledge, 2003).

${ }^{75}$ Rob Walker, 'State Sovereignty and the Articulation of Political Space/Time', Millennium: Journal of International Studies, 20:3 (1991), pp. 445-61; Cynthia Weber, Simulating Sovereignty: Intervention, the State, and Symbolic Exchange (Cambridge: Cambridge University Press, 1995).

76 Jim George, 'Realist "Ethics”, pp. 195-223; Rob Walker, Inside/Outside.

${ }^{77}$ Cynthia Weber, Simulating Sovereignty and Faking It: US Hegemony in a 'PostPhallic' Era (Minneapolis: University of Minnesota Press, 1999); David Campbell, Writing Security: US Foreign Policy and the Politics of Identity, revised edition (Minneapolis: University of Minnesota Press, 1998).

${ }^{78}$ See Stanley Hoffman, 'An American Social Science: International Relations', Janus and Minerva: Essays in the Theory and Practice of International Relations (Boulder: Westview Press, 1987); and Steve Smith, 'The Self-Images of a Discipline: A Genealogy of International Relations Theory', in Ken Booth and Steve Smith (eds) International Relations Theory Today (University Park: Pennsylvania State University Press, 1995), pp. 1-37. 
being-in-the-world. ${ }^{79}$ But the enthusiasm with which poststructuralist IR has focused on otherness and difference is problematic in several ways. Firstly, in their injunction that all difference is equally significant and equally contestable, poststructuralist analyses in IR have operated with an 'undistinguished postmodern vision of difference' that flattens out context and specificities. ${ }^{80}$ In a skilful analysis of the need for historicity in IR, Richard Ashley claims precisely this undifferentiated vision of difference when he states that 'all other grounds are equally arbitrary, equally the effects of attempts to decide the undecidable, and [...] equally subject to political dispute'. ${ }^{81}$ Why equally? What are the effects of this equalising gesture on our understanding of otherness? I single out this passage because it is a vision that has been replicated by many poststructuralist engagements in IR, which aim to practice a sense of responsibility to others on the grounds of their being equally worthy of our attention. I find this assumption highly problematic. As I highlight later in my analysis of Jenny Edkins' ethics of responsibility, this emphasis on our equal responsibility and on their equal worthiness has the unintended effect of flattening all difference into an undifferentiated 'pile of subversive marginality'. ${ }^{82}$

Secondly, as repeatedly mentioned earlier in this article, I find that this prompt affirmation of the equally subversive nature of all difference creates a postcolonial subject cum object, who - very much like Cixous' Algeria and like Derrida's Chinese writing - lacks texture and depth, frozen into a portrait of difference that is nothing but resistance against the West. Such an idealisation of the oppressed and of the marginalised is many times remarkable by the paradoxical absence of their voices or perspectives from analyses that problematise contemporary practices of security, of the state, of sovereignty, among others. It is not uncommon to find that the legacy of colonialism and the manner in which (post)colonial subjects negotiate their political identities and practices in an age of postmodernity is simply left unexplored.

\section{When was the postcolonial in International Relations? ${ }^{83}$}

I illustrate the latter point by examining Roxanne Doty's analysis of antiimmigrantism in Western democracies. In a chapter that zooms into the issue of racism and anti-immigrantism in contemporary France, Doty focuses on the contradictory relation between 'the schizophrenic pole of desire' of the French state toward 'infinite freedom, defying boundaries, promoting perpetual flow of goods, capital, and human bodies' and the centripetal desire towards order, unquestioned identity and security. ${ }^{84}$ This tension between totalising and

79 The expression 'subjugated knowledges' was used by Michel Foucault in 'Two Lectures' in Collin Gordon (ed.), Power/Knowledge: Selected Interviews and Other Writings 1972-1977 (New York: Pantheon Books, 1980), pp. 78-108.

${ }^{80}$ See Alina Sajed, 'Late Modernity/Postmodernity'.

81 'Living on Borderlines', p. 279, emphasis added.

82 Rey Chow's expression in Writing Diaspora, p. 59.

${ }^{83}$ My subtitle is inspired by Stuart Hall's question posed in 'When Was the "PostColonial"? Thinking at the Limit', in Iain Chambers and Lidia Curti (eds), The PostColonial Question. Common Skies, Divided Horizons (London and New York: Routledge, 1996), pp. 242-60.

84 Anti-Immigrantism in Western Democracies. Statecraft, Desire, and the Politics of Exclusion (London and New York: Routledge, 2003), p. 58. 
non-totalising tendencies has translated into policies that initially allowed migrants to come into France almost without restrictions 'as cheap and mobile foreign labour'. ${ }^{85}$ Doty adds that the increased migration of mobile cheap labour also meant the relegation of such labour to the fringes of French society. The tension that became apparent was between a certain ideal to which French society held itself, as the cradle of human rights, and the reality of large groups of people living in a state of sordid marginalisation. ${ }^{86}$

Through a thoughtful analysis of post-Second World War French policies regarding migration, Doty establishes a connection between the need of French society for cheap and dispensable labour, and the racism that permeates French political discourses and practices. Moreover, she explores the paranoid desire of the state to reconfigure its identity to the standard of homogeneity, while excluding from participation those on whose labour and presence it depends for the satisfaction of its schizophrenic desire for deregulation and unimpeded commercial flows. At one point, Doty uses Homi Bhabha's conceptualisation of the nation as the disjunction between the pedagogical and the performative. ${ }^{87}$ When Bhabha refers to the splitting between the 'pre-given historical origin in the past' (the pedagogical) and the gathering of incoherent fragments into one coherent national whole (the performative), in the case of France, the most important element in understanding the alchemy between national identity, immigration and racism is colonialism. I cannot see how the issue of migration in France can be discussed without making mention, and exploring the inevitable links between colonial and postcolonial exploitation of cheap labour.

Regrettably, Doty's analysis of France does not mention the terms 'colonial' or 'colonialism'. To understand the absurdity of anti-immigration policies in France, the roots of racism towards migrants, and the inexplicable fear and anxiety of this society towards Muslim and African migrants in particular, one has to understand the mechanisms, stereotypes, and desires put in place and performed with the onset of the colonial rule in Africa. Max Silverman makes it clear that one cannot speak of a clear break between the colonial and postcolonial eras in France. In fact, 'contemporary France has been formed through and by colonization'. ${ }^{88}$

Doty's omission of the postcolonial from the analysis of contemporary French society implies that the redefinition of 'what it means to be French', as she put it, has nothing to do with the colonial legacy and its continuing reconstitution into discriminatory policies and racist discourses. Therefore, to understand why France refused in 1993, through the amendment of Article 23 of the Code de la Nationalité Française, to grant automatic citizenship to the children born in France coming from migrant families, and thus to abandon jus soli, one needs to see who in particular was targeted by these laws. Most of the European migrants, such as

${ }^{85}$ Ibid., p. 60.

${ }^{86}$ This tension receives an attentive treatment in Étienne Balibar's 'Rights of Man' and 'Rights of the Citizen'. The Modern Dialectic of Equality and Freedom', Masses, Classes, Ideas. Studies on Politics and Philosophy Before and After Marx (London and New York: Routledge, 1994) pp. 39-59.

${ }^{87}$ Homi Bhabha, 'DissemiNation: Time, Narrative and the Margins of the Modern Nation', The Location of Culture (London and New York: Routledge, 2004), pp. 199-244.

${ }^{88}$ Max Silverman quoted in Hafid Gafaiti, 'Nationalism, Colonialism, and Ethnic Discourse in the Construction of French Identity', in Tyler Stovall and Georges van den Abbeele (eds), French Civilization and its Discontents. Nationalism, Colonialism, Race (New York: Lexington Books, 2003), p. 209. 
those from Italy and Portugal, had been assimilated into French society. It is the North Africans (Maghrébins) and the sub-Saharan Africans who were intended as targets, because their 'visibility' and their difficulties in 'integration' made them undesirable to France. Moreover, what does this 'visibility' mean? Is it simply a reference to race? It is not only a racial reference. As Albert Memmi insightfully remarked, the immigrés are constant reminders of the colonial disillusion, they are 'the illegitimate children [bâtards] of the colonial affair'. ${ }^{89}$ Consequently, their visibility is not merely a racial visibility, but a reminder of the painful state of anomie in which the French Republic has been living since 1789.

I explored Doty's omission of the postcolonial in understanding the mechanisms of racism and anti-immigrantism in contemporary France because I find it symptomatic of a lack of preoccupation in poststructuralist IR with the colonial roots of current practices of marginalisation and racism. But one could advance the argument that, in this context, exploring the colonial roots of poststructuralism tells us little if anything about contemporary poststructuralist IR and its sins of omission. I disagree. It is sobering to examine the colonial roots of poststructuralism because it allows for a better understanding of those things left unsaid by poststructuralist IR. Focusing on the engagements with (Algerian) difference of a few Franco-Maghrebian authors associated with the beginnings of poststructuralism has several outcomes: firstly, it illuminates the historical context out of which poststructuralism emerged; secondly, we are prompted to ask questions about the current disconnect within poststructuralist analyses in IR between (post)colonial contexts and critical incursions into world politics; and thirdly, it provides a crucial background to understanding how current poststructuralist explorations in IR replicate the facile idealisation of the postcolonial subject signalled in the texts of Derrida, Cixous, and Lyotard.

\section{Postcolonial intractability in International Relations}

I now focus on Jenny Edkins' work on visuality and subjectivity to exemplify my criticism of the practice of deconstruction in IR, and of its problematic politics of engaging otherness. In an article entitled 'Exposed Singularity', Edkins muses primarily on the politics and on the ethical implications of the reception of images. ${ }^{90}$ Her article focuses on the production of images of children affected by political crises, such as genocide and famine. Thus, Edkins chooses to look at the portraits produced by celebrated photographer Sebastião Salgado, which, in her opinion, elicit a response from us as viewers. She also reflects on the mug-shots of children taken in the infamous prison of Tuol Sleng (Cambodia), which leave the viewers with the impossibility to respond adequately. Edkins aptly complements and juxtaposes Derrida's theory of responsibility (from his The Gift of Death), and Jean Luc Nancy's formulation of 'being singular plural' (from his The Inoperative Community and Being Singular Plural). She does so in order to illuminate the ways in which viewing these different and disturbing photographs constructs us (the

${ }^{89}$ Portrait du décolonisé arabo-musulman et de quelques autres (Paris: Gallimard, 2004), p. 97, author's translation.

90 Jenny Edkins, 'Exposed Singularity', Journal for Cultural Research, 9:4 (2005), pp. 359-86. 
viewers) as exposed selves, in need to respond (and thus to take responsibility in the events). Edkins' reading of the photographs becomes the pretext to reflect on the ways in which a political community might be envisaged, one where we would perceive ourselves not as individuals assembled together in a community, but as 'being singular plural' or as 'being' in-common'. Put differently, she attempts to understand how we arrive to perceive ourselves as individual and separate subjects in the first place.

While I find Edkins' article intriguing with respect to challenging taken for granted notions such as subjectivity, responsibility and ethics, there are several points in the text, which deserve further reflection. Firstly, Edkins makes a distinction between the authentic subjectivity evoked by a portrait photograph, and the state-imposed (and thus inauthentic) subjectivity of identity photos (mugshots). Her analysis attempts to question the facile reading of the photos of Cambodian children as simply victims in need of rescue, and to explore the ways in which these photos might be read as portraits in their own right. However, an inadvertent juxtaposition insinuates itself in her analysis, between the positive aura surrounding Salgado's photos, which are more explicitly described as portraits that displace and expose us, ${ }^{91}$ and the Cambodian mug-shots that are described more negatively as leaving us unable to respond adequately - an inevitable tendency perhaps considering the circumstances under which they were taken. The question that arises is the following: what makes 'us' read more positively Salgado's photos? Why is their character as portraits not questioned, why are 'we' sure that these photos evince the subjects as authentic and hence, according to Edkins, as 'someone' and not as 'something'?' And in the same vein, why are the photos (mug-shots) of Cambodian children more difficult to read as portraits?

Following Jean-Luc Nancy's theory of community, Edkins employs the notions of being-with or being-in-common to challenge assumptions of individuality, and to posit that we are always and simultaneously being-with, both us and me at the same time. This ethical vision entails that 'we are inevitably already engaged with what is happening or has happened'. ${ }^{93}$ Nancy's conceptualisation allows for a different interaction with and reading of the Cambodian photos insofar as it exposes that there is no 'us' and 'them', but that 'we' are always 'us', always already engaged: 'It is not just that we recognize ourselves in these portraits (these people could have been "us") but that they are "us". 94

This ethical vision of 'they are us' inadvertently conveys a sense of equality that erases the specificity of 'their' experience. What would a postcolonial reading of "they are "us"' look like - one that would account for the power relationships and the attending socio-political hierarchies between 'they' and 'us'? Are they really us? Can 'we' really be them? Do not our privileged geopolitical position and our entrenchment in a Western institution place such an equality (and interchangeability) under a legitimate question mark? Do they not make it tenuous, albeit very attractive? More importantly, who is this 'we' in this article? Why does this 'we' author responsibility? Perhaps Nancy's notion of being-in-common aims to alleviate precisely this sense of authorship and author-ity, but I argue that a

\footnotetext{
91 Ibid., p. 362.

92 Ibid., p. 364.

93 Ibid., p. 382, emphasis in original.

94 Ibid., p. 384, emphasis added.
} 
postcolonial reading of "they are "us" makes such a claim in need of further critical exploration. Moreover, the inadvertent distinction made between the subjectivity evinced by Salgado's photos and the questionable (and questioned) subjectivity emanating from the Cambodian mug-shots seems to override the being-in-common impulse, and to place the author-ity of responsibility and of subjectivity squarely with this 'we'. It is precisely this sort of fantasy of our interchangeable positions and subjectivities ('they are "us") that depoliticises difference and erases its specificity. Cultural critic Rey Chow remarks how poststructuralism/postmodernism, by perceiving all others to be equally different, implicitly treats them as interchangeable, thus levelling them into one pile of 'subversive marginality', ${ }^{95}$ which really serves to reinforce our sense of sophisticated, socially engaged, and reflexive selves rather than theirs. Why is it that is only us (the reader, the viewer, the Western academic or critic) who have the privilege to respond (and thus to be responsible) to our imagined others?

Perhaps this is the source of Edkins' predicament as regards the aporia of responsibility in front of these photos: they confront us with a subjectivity that challenges our liberal notions of agency and seeing. More importantly, it seems to be the case (implied by Edkins' analysis) that it is the viewer who determines the subjectivity of the other: the Cambodian mug-shots are more difficult to read as portraits because they are taken illegitimately by a photographer who was complicit with the murderous regime of the Khmer Rouge. In contrast, Salgado's children emanate dignity and presence since their images are captured by a well-known and socially engaged photographer. Consequently, it is implied that they are authentic representations of these children. What we have here is also a claim to the authenticity and interchangeability of the (post)colonial subject sanctioned by the knowing and knowledgeable gaze of the Western critic.

More to the point, to reiterate the very intriguing questions Azzedine Haddour poses in his Colonial Myths, are non-Western perspectives doomed to be always rendered as absences, as the limits of Western knowledge, and/or to be 'locked in the prisonhouse of Western metaphysics, condemned not to have cultural [and political] texture outside as an outside?' ${ }^{96}$ I chose to engage Roxanne Doty's and Jenny Edkins' analyses because their research is inscribed within a larger effort of critical IR scholars to tackle the practices of (and the consequences thereof) 'symbolic power'97 in IR. ${ }^{98}$ The power to 'mark, assign and classify', to perform 'ritualized expulsions', 99 and to symbolically (and materially) confine others to stereotyped images of who/what they are has tremendous consequences in foreign policy. These powers are instrumental in deciding whether or not to intervene in situations of political conflict, in establishing the parameters of aid and development, and in framing our encounters with others.

95 Chow, Writing Diaspora, p. 59.

${ }^{96}$ Haddour, Colonial Myths, p. 159, emphasis added.

97 Stuart Hall, 'The Spectacle of the "Other"', in Stuart Hall (ed.), Representation: Cultural Representations and Signifying Practices (London: Sage Publications and The Open University, 1997), p. 259.

98 Jenny Edkins does not situate her work within IR and does not consider herself an IR scholar (personal communication). However, I included her in this statement since her work does address certain issues critical for IR, and thus has significant implications for how we think critically about and interrogate the discipline.

99 Hall, 'The Spectacle of the "Other"'. 
There is a disconnect between the poststructuralist critic's self-avowed mission to create space for other forms of being and thinking about the political, and her implicit elision of non-Western views and subjectivities. Such a disconnect stems from the above mentioned refusal of the poststructuralist 'subject-inestrangement $^{\prime 100}$ to speak for the other out of a fear that, since the Western discourse and practices have been involved in so much violence, 'any intervention on behalf of the other [...] will be contaminated by that history and therefore futile'. ${ }^{101}$ More to the point, poststructuralist theorists of IR assume that a deconstruction of the Western-centric and state-centric discourse/practice is somehow a sufficient exercise to undermine not only the rigid disciplinarity of the field, but also that it constitutes a sufficient 'ground-clearing gesture'. ${ }^{102}$

How then is it that there has been no significant engagement, within critical IR, with the colonial roots of poststructuralism? If poststructuralism arose out of the violence of the Algerian War, why is there no mention of the initial anti-colonial drive that, according to Young, started the project of deconstruction? If deconstruction only makes sense within the violence of the (French) colonial project, then one can make the argument that current practices of deconstruction operate with a decontextualised and dehistoricised understanding of deconstruction, which is divorced from its initial (anti-colonial) preoccupations. Is there any connection between Derrida's failure to transcend the limits of the Western-centric discourse he wanted to deconstruct, and critical IR's inability to exceed the disciplinary boundaries it claims to unsettle? As is evident, I argue that both failures can be traced to a lack of a serious engagement with (post)coloniality and with its implications.

Nevertheless, if so far I have discussed the dangers of disciplining 'natives' through an easy idealisation of marginality (identified as one of the dangers of an exclusive focus on deconstruction), what can be said about nativising disciplines? In other words, to echo my earlier analysis of Derrida's hyphenated identity, what function does the hyphen that separates and unites poststructuralism and postcolonialism in IR perform? What would be the dangers involved by the gesture of erasing such a hyphen? Perhaps one such danger can be perceived in terms of the concerns and issues of what is known as the 'Third World' being reabsorbed by an 'increasing momentum of instrumentalism' disseminated globally, which attempts to gather under one umbrella of postmodernism, feminism, and postcolonialism, and thus erase and level differences among them. ${ }^{103}$ Also, such an association or, to put it differently, such a rethinking of poststructuralism as a postcolonial theory, ${ }^{104}$ would make the assumption that postcolonialism is beyond critique, that

\footnotetext{
${ }^{100}$ Richard Ashley, 'The Achievements of PostStructuralism', in Steve Smith, Ken Booth and Marysia Zalewski (eds), International Theory: Positivism and Beyond (Cambridge: Cambridge University Press, 2002), p. 249.

${ }^{101}$ Varadharajan, Exotic Parodies, p. xvi.

${ }^{102}$ See fn. 75 .

${ }^{103}$ Chow, Writing Diaspora, p. 69.

104 There are voices who claim that the poststructuralism associated with deconstruction can be better understood as an offshoot of postcolonial theory. In this regard, see David Macey, Dictionary of Critical Theory (London: Penguin Reference, 2001), p. 309; Pal Ahluwalia, 'Out of Africa'; Azzedine Haddour, 'Remembering Sartre' and 'The Signifier of the Outside', Colonial Myths, pp. 155-74.
} 
it truly embodies and represents the interests of Third World peoples, and that postcolonial intellectuals are not guilty of the same commodification charges levelled against Western academia.

This assumption would be a very mistaken one. Not only has postcolonialism been critiqued on grounds of its reducing Third World peoples to mere resistant images to Western hegemonic practices, but postcolonial intellectuals have been perceived as nothing more than Western-educated, Western-minded scholars who are engaged in reinscribing the imaginative geography of the West. ${ }^{105}$ Anthony Appiah has called postcolonial intellectuals the 'comprador intelligentsia' (the link to commodification is unmistakable) and suggests that this sort of intellectual is not so much a mediator, but an appropriator of the 'native's' voice. ${ }^{106}$ But this retracing of poststructuralism's anti-colonial drive has, in my opinion, important ramifications for current practices in critical theory in IR, insofar as it allows for the possibility of transcending the Western frame of reference that so pervades the discipline.

By this transcendence, I do not mean that we should try to recapture a long-lost 'authentic' nativism, or to disentangle ourselves completely from Western influence. I have no such illusions. In fact, I believe that such a project is as dangerous as the European colonial one, if post-independence Algeria teaches us anything about facile erasures of memory and desires for lost origins. ${ }^{107}$ Rather I conceive of the construction and portrayal of otherness in such a manner as to transcend notions of mystery, unambiguous victimhood, and irretrievable silence. What Rey Chow calls a 'context of cultural translation' illustrates the manner in which 'others' are also entangled in 'the contradictions of modernity, such as the primitivisation of the underprivileged'. ${ }^{108}$ Viewed in this light, 'coevalness of cultures' does not imply a bland and meaningless equality, but 'the co-temporality of power structures'. 109

105 These searing critiques appear in the works of postcolonial and/or Marxist theorists who have been cited earlier in fn. 13. See also, Gayatri Chakravorty Spivak, A Critique of Postcolonial Reason. Toward a History of the Vanishing Present (Cambridge, Massachusetts: Harvard University Press, 1999).

106 Appiah, 'Is the Post in Postmodernism the Post in Postcolonial?', p. 348.

${ }^{107}$ See Benjamin Stora, La gangrène et l'oubli. La mémoire de la guerre d'Algérie (Paris: La Découverte/Poche, 2007).

${ }^{108}$ Chow, Primitive Passions: Visuality, Sexuality, Ethnography, and Contemporary Chinese Cinema (New York: Columbia University Press, 1995), p. 196.

109 Ibid. 